\title{
Expression Patterns of BMP15 Gene in Folliculogenesis of Buffalo (Bubalus bubalis)
}

\author{
Jinfeng Liu, ${ }^{1,2}$, Yanhong Cao ${ }^{3}$, Tong Feng', Laiba Shafique ${ }^{1}$, Chan Luo ${ }^{1}$, \\ Peng Zhu ${ }^{1,4, *}$ and Qingyou Liu ${ }^{1, *}$ \\ ${ }^{I}$ State Key Laboratory for Conservation and Utilization of Subtropical Agro- \\ Bioresources, Guangxi University, Nanning, Guangxi 530005, PR China \\ ${ }^{2}$ Guangxi Veterinary Research Institute, Guangxi Key Laboratory of Veterinary \\ Biotechnology, Nanning, Guangxi, 530001, China \\ ${ }^{3}$ The Animal Husbandry Research Institute of Guangxi Zhuang Autonomous Region, \\ Nanning 53001, PR China \\ ${ }^{4}$ Guangxi Key Laboratory of Beibu Gulf Marine Biodiversity Conservation, Qinzhou \\ University, Qinzhou, Guangxi 530005, PR China
}

Jinfeng Liu and Yanhong Cao are the co-first authors.
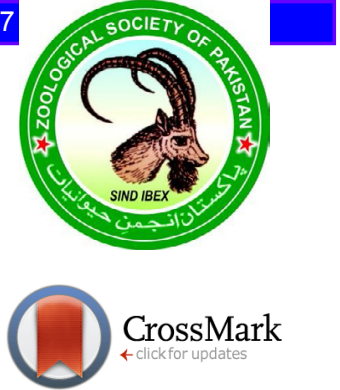

Article Information

Received 21 December 2018

Revised 25 January 2019

Accepted 31 January 2019

Available online 01 October 2019

Authors' Contribution

QL designed the experiment. JL cloned the $B M P 15$ gene and drafted

the manuscript. YC analyzed the expression pattern of $B M P 15$ gene in folliculogenesis. TF analyzed the data. $C L$ analyzed the expression pattern of $B M P 15$ gene in embryogenesis. PZ did the immunohistochemistry work. LS revised the manuscript.

Key words

Buffalo, BMP15, Expression pattern, Folliculogenesis, Embryogenesis.

\section{INTRODUCTION}

$I^{2}$ $\mathrm{n}$ Asia, livestock including buffalo has been considered a vital part of agriculture for over 5000 years. But, in spite of its pronounced significance in the fiscal zone, it makes available milk, meat, and draft for agriculture, buffalo remains quite ignored. The reproductive efficacy also remains deprived chiefly due to late puberty, reduced expression of estrus, summer anoestrus, long postpartum service period and low conception rate (Singh, 2012). So to shed light on the mechanism of folliculogenesis and embryogenesis are central for enlightening the reproductive efficacy of buffalo. The method of ovarian folliculogenesis consists of production and distinction of the constitutive cells in developing germ

\footnotetext{
* Corresponding authors: 476819435@qq.com;

qyliu-gene@qq.com

0030-9923/2020/0037-0001 \$ 9.00/0

Copyright 2020 Zoological Society of Pakistan
}

cells. Ovarian folliculogenesis is categorized by the development of oocytes from the primordial germ cells stage to the mature ovulating Grafian follicle stage.

The whole process is organized by both extra ovarian elements, e.g. pituitary gonadotropins, and locally produced paracrine factors, bidirectional interaction between the oocyte and the adjacent somatic cells, it is broadly acknowledged that oocyte directs the differentiation of granulosa cell and promote the development of follicles. Oocyte is able to secrete the solvable paracrine growth factors (such as BMP15 and GDF9) by performing on its immediate granulosa cells, in turn to control the selfdevelopment of oocyte. In pre-antral follicles, the oocyte leads granulosa cells to control the development of oocyte. The interaction of oocyte-cumulus cell has been described to accomplish the prevention of cumulus cell luteinization and regulating steroidogenesis, inhibit the synthesis and suppressing LH receptor manifestation.

Bone morphogenetic protein 15 (BMP15 also known as GDF9B) are interrelated members of the transforming 
development element b (TGFb) superfamily that are formed by the ovary and have intense effects on fertility (Elvin et al., 2000; McNatty, 2003). In mice, GDF9 (Dong, 1996) but not BMP15 (Yan, 2001) is crucial for usual follicular growth. But, in sheep, both GDF9 and BMP15 are vital for typical follicular development (Juengel, 2002). Several studies (Otsuka et al., 2000, 2001; Otsuka and Shimasaki, 2002) also recognized three most important biological purposes of $B M P 15$ in the ovary. Firstly, $B M P 15$ is a forceful stimulator of GC mitosis; Secondly, BMP15 prevents the manifestation of FSH receptor mRNA in GCs, causing the consequent suppression of FSHinduced progesterone synthesis as well as FSH-induced manifestation of a battery of mRNAs in GCs; and Thirdly, $B M P 15$ excites the expression of kit ligand mRNA in GCs. The significance of $B M P 15$ in fertility in sheep was clarified that naturally taking place alterations in the $B M P 15$ gene in Inverdale $(\mathrm{FecX})$ and Hanna $\left(\mathrm{Fec} \mathrm{X}^{\mathrm{H}}\right)$ ewes triggered the rise in the rate of ovulation in heterozygotes due, in part, to an increased FSH sensitivity of GCs but initiated infertility in homozygotes due to a block in the primary stage of folliculogenesis (Galloway, 2000).

Mice with directed omissions in the BMP15 gene are sub-fertile, indicating the significance of BMP15 in the mouse fertility. The sound effects of transmutations in the BMP15 gene on the development of placenta and the fertility of cattle, especially in ovarian folliculogenesis, are unfamiliar and well-intentioned of advance study. In this research work, the duplicating and manifestation study of the water buffalo BMP15 were studied.

\section{MATERIALS AND METHODS}

\section{Collection of animal tissues samples}

The water buffaloes were slaughtered by exsanguination and the required tissues including cardiac, alveolar, renal, hepatic, neural, oocytes, spermatocytes, skin, bone, muscle tissue, genital ridge, hypophysis, hypothalamus, granulosa tissues and cumulus tissues were removed. After that the required tissues were instantaneously freezed in liquid nitrogen and stored at $-80^{\circ} \mathrm{C}$ before handling for the isolation of RNA.

\section{Preparation of RNA and cDNA synthesis}

The total RNA was extracted from removed tissues by using the RNAiso Plus reagent (TAKARA, Daliang, China) succeeding the manufacturer's specifications. The concentration, purity and integrity of RNA were detected by NanoDrop 2000 (GENE, USA) and agarose gel electrophoresis, separately. Synthesis of cDNA was executed using the PrimeScript 1st Strand cDNA Synthesis (TAKARA, Daliang, China) from $2 \mu \mathrm{g}$ of total RNA from each the removed tissues.

\section{Cloning of BMP15 gene in water buffalo}

RT-reactions were implemented as earlier defined by our lab (Huang, 2010), one pair of primers was considered and chosen for the final PCR amplification based on the Bos taurus BMP15 sequence (GenBank: NM_001031752.1) (Table I). The PCR was accomplished using the PrimeScript RT-PCR Kit (TAKARA, Daliang, China) at $94^{\circ} \mathrm{C} 5 \mathrm{~min}, 94^{\circ} \mathrm{C} / 30 \mathrm{~s}, 55^{\circ} \mathrm{C} / 30 \mathrm{~s}$ and $72^{\circ} \mathrm{C} / 1.5$ min for a total of 35 cycles, with a final extension at $72^{\circ} \mathrm{C}$ for $7 \mathrm{~min}$ in a Biometra thermocycler. The PCR products were cloned into pMD-18T (TAKARA, Daliang, China) and then were sequenced by Invitrogen. The sequences were counting by DNAStar 7.1 that have been deposited to Gene Bank under accession number JQ326273.1.

\section{Software for bioinformatics analysis}

All sequence outputs (ABI trace files) were examined with the DNAStar Seqman module. Sequences were trimmed at high stringency. Software for bioinformatics analysis was list in (Table II). The BLAST search program was used to find homologies with nucleic acids and protein sequences. The ORF Finder was used to confirm open reading frames and translated to protein sequences. The physical and chemical properties of the putative BMP15 protein were predicted using the software on the ExPASy server.

Table I.- Primers used to amplify the BMP15 gene and expression analysis.

\begin{tabular}{|c|c|c|c|c|c|}
\hline Products & Amplicon length (bp) & Primer name & Sequences $\left(5^{\prime} \rightarrow 3^{\prime}\right)$ & Annealing temp. $\left({ }^{\circ} \mathrm{C}\right)$ & Note \\
\hline \multirow[t]{2}{*}{$B M P 15$} & 1185 & Bmp15-F1 & ATGGTCCTTCTGAGCATCC & 55 & CDS cloning \\
\hline & & Bmp15-R1 & TCACCTGCATGTACAGGACT & & \\
\hline \multirow[t]{2}{*}{$\mathrm{q} B M P 15$} & 156 & Bmp15-qRT-F & AAAGCCCAACCAATCACT & 55 & RT-qPCR \\
\hline & & Bmp15-qRT-R & GACACACGAAGCGGAGTC & & \\
\hline \multirow[t]{2}{*}{$q \beta$-actin } & 199 & $\beta$-actin-qRT-F & ACCGCAAATGCTTCTAGG & 55 & RT-qPCR \\
\hline & & $\beta$-actin-qRT-R & ATCCAACCGACTGCTGTC & & \\
\hline
\end{tabular}


Table II.- Software for bioinformatics analysis.

\begin{tabular}{lll}
\hline Software & Website & Function \\
\hline BLAST & http://blast.ncbi.nlm.nih.gov/Blast.cgi & Assemble sequences \\
ORF Finder & http://www.ncbi.nlm.nih.gov/gorf/gorf.html & Find CDS \\
MEGA5.0 & - & Constructed phylogenetic tree \\
DNAMAN & - & Multiple sequence alignment \\
EXPASY & $\mathrm{http://web.expasy.org/protparam/}$ & Predict protein property \\
SMART[1] (Letunic, 2017) & $\mathrm{http://smart.embl-heidelberg.de}$ & Predict protein domains \\
SignIP[2] (Petersen, 2011) & www.cbs.dtu.dk/services/SignalP/ & Predict signal peptides \\
Softberry & http://linux1.softberry.com/berry.phtml?topic=protcompan\& & Predict the sub-cellular localization \\
& group=programs\&subgroup=proloc & of protein \\
DNAStar & - & Predict secondary structure of protein \\
InterProScan & $\mathrm{http://www.ebi.ac.uk/interpro/search/sequence-search}$ & Predict protein domains \\
I-TASSER[3] (Roy, 2010) & http://zhanglab.ccmb.med.umich.edu/I-TASSER/ & Predict protein structure \\
\hline
\end{tabular}

Tissue distribution of water buffalo BMP15 mRNA

The removed tissues included cardiac, alveolar, renal, hepatic, neural, skin, bone, muscle, genital ridge, ovary, testis, hypophysis, hypothalamus, granulosa cell and cumulus cell as temples to study the distribution of the water buffalo $B M P 15$ mRNA using the $\mathrm{q} B M P 15$ primers (Table I). The PCR mixtures contained $1 \mathrm{uL} 50$ ng/ $\mu \mathrm{L}$ cDNA, $0.3 \mu \mathrm{L}$ each of $10 \mu \mathrm{M}$ forward and reverse primers, $8.7 \mu \mathrm{L}$ PCR-grade Water, and $10 \mu \mathrm{L}$ of Premix Taq $^{\text {TM }}$ (TAKARA, Daliang, China). Reaction conditions were $95^{\circ} \mathrm{C}$ for $5 \mathrm{~min} ; 40$ cycle of $95^{\circ} \mathrm{C}$ for $10 \mathrm{~s}, 55^{\circ} \mathrm{C}$ for $30 \mathrm{~s}, 72^{\circ} \mathrm{C}$ for $30 \mathrm{~s}$; with a final extension at $72^{\circ} \mathrm{C}$ for $7 \mathrm{~min}$ in a Biometra thermocycler.

\section{Collection of COC and embryo and reverse transcription}

Cumulus-oocyte-complexes (COC), parthenogenetic activation, embryo culture, collection and reverse transcription were according to the method reported by our lab (Li et al., 2005; Li, 2006; Shi, 2007). COC were collected from different diameter follicles, including 0-2 mm, 2-4 mm, 4-6 mm, 6-8 $\mathrm{mm}$ and more than $8 \mathrm{~mm}$.

\section{Quantitative real-time PCR}

To study the distribution of the water buffalo BMP15 mRNA during folliculogenesis and embryogeneis using the primers (Table I). The PCR mixtures contained 1 $\mathrm{uL} 50 \mathrm{ng} / \mu \mathrm{L}$ cDNA, $0.3 \mu \mathrm{L}$ each of $10 \mu \mathrm{M}$ forward and reverse primers, $8.7 \mu \mathrm{L}$ PCR-grade Water, and $10 \mu \mathrm{L}$ of SYBR Master Mix (TAKARA, Daliang, China). Reaction conditions were $95^{\circ} \mathrm{C}$ for $5 \mathrm{~min} ; 40$ cycle of $95^{\circ} \mathrm{C}$ for $10 \mathrm{~s}$, $55^{\circ} \mathrm{C}$ for $30 \mathrm{~s}, 72^{\circ} \mathrm{C}$ for $30 \mathrm{~s} ; 95^{\circ} \mathrm{C}$ for $5 \mathrm{~s}, 65^{\circ} \mathrm{C}$ for $1 \mathrm{~min}$, $97^{\circ} \mathrm{C}$ continuous, 1 cycles; $40^{\circ} \mathrm{C}$ for $10 \mathrm{~s}$. SYBR Green was used to detect specific PCR products. Amplification and detection of SYBR Green were performed with the ABI 7500 Instrument. At least three sets of embroys were analyzed for BMP15 examined, and all PCRs were conducted in triplicates. The comparative $\mathrm{C}_{\mathrm{T}}$ method was used for relative quantification of target gene expression levels. The quantification was normalized to the control $\beta$-actin gene. The calculation of $\Delta \Delta \mathrm{C}_{\mathrm{T}}$ involved using the $<2 \mathrm{~mm}$ sample $\Delta \mathrm{C}_{\mathrm{T}}$ value as an arbitrary constant to subtract from all other $\Delta \mathrm{C}_{\mathrm{T}}$ sample values. The $\Delta \mathrm{C}_{\mathrm{T}}$ value was determined by subtracting the $\beta$-actin $\Delta \mathrm{C}_{\mathrm{T}}$ value for each sample from the BMP15 gene $\Delta \mathrm{C}_{\mathrm{T}}$ value of the sample. Fold-changes in the relative mRNA expression of the target gene were determined using the formula $2^{-\Delta \Delta} \mathrm{CT}$.

\section{Immunohistochemical localization of BMP15}

Swamp Buffalo ovaries and testis were sampled from the local slaughterhouse, and instantly fixed for 24 $\mathrm{h}$ in PBS containing 4\% PFA (paraformaldehyde) in $4^{\circ} \mathrm{C}$, and then administered in steadily alcohol and xylene, infiltrated with paraffin in a Biological Tissue Automatic Dehydration Machine, last embedded in paraffin. Serial sections 5-7 uM thick, were cut from laica RM 2235 rotary microtome, and then mounted on poly-L-lysine coated slides, dried in the $50^{\circ} \mathrm{C}$ drying oven overnight. Five to ten sections were processed in 1:49 APES: acetone for 60 s to prevent the sections fall off, then deparafinized in xylene, and rehydrated. Then three 5-min washes with $0.1 \%$ Tween-20 in PBS (PBS-T) in a horizontal shaker, endogenous peroxidase was removed by incubating the deparaffinized sections in $3 \%$ hydrogen peroxide in methanol for $30 \mathrm{~min}$. After three $5 \mathrm{~min}$ washes with PBS-T on a horizontal shaker, sections were treated with microwave heat-induced epitope retrieval three 6-min and $90 \%$ firepower with $5 \mathrm{~min}$ interval and cooled for $2 \mathrm{~h}$ to room temperature. Wash three times 5 min each in PBS-T, sections were incubated in PBS-T contain 1\% Triton $\mathrm{X}-100$ for $30 \mathrm{~min}$, then wash three times $5 \mathrm{~min}$ each in PBS-T, wiped off the surrounding liquid of the sections, drawn a circle around the tissue sections with a Super Pub 
Pen (ZLI-9305, Beijing Solarbio Science and Technology Co., Ltd.), then dripped 5\% BSA onto the sections incubate for $45 \mathrm{~min}$ in room temperature to minimize non-specific binding. After that, sections were incubate in $4^{\circ} \mathrm{C}$ overnight with the rabbit polyclonal BMP15 (sc-27324, SANTA) antibody diluted 1:80 in PBS-T. The next day, the sections were incubated in $37^{\circ} \mathrm{C}$ for 45 min to ensure the antibody for the best combination with the target antigens. After three times washes, the sections were incubated with goat anti-rabbit Biotin-SP-conjugated antibody (SA00004-4, Protein Tech Group, Inc.) for $45 \mathrm{~min}$ at room temperature and $45 \mathrm{~min}$ at $37^{\circ} \mathrm{C}$. Sections were washed three times in PBS-T before being incubated with Peroxidase-conjugated Streptavidin (SA00001-0, Protein Tech Group, Inc.) for $45 \mathrm{~min}$ at $37^{\circ} \mathrm{C}$. After three $5 \mathrm{~min}$ washes with PBS-T, sections were incubated with DAB color development kit for $2 \mathrm{~min}$ at room temperature and then counterstained with hematoxylin, dehydration in a grade alcohol and mounted with Neutral Balsam. Negative controls were performed in which the primary antibody was replaced with rabbit IgG. All other incubations and washes were performed on a horizontal shaker except antibodies incubation. The sections were observed with a Nikon ECLIPSE E800 photomicroscope (Nikon, Tokyo, Japan).

\section{Data of analysis}

The expression of mRNA was investigated using SPSS software and SigmaPlot. One-way repeatedmeasures analysis of variance, followed by multiple pairwise comparisons using Student-Newman-Keuls Multiple Comparisons Test, was used for analysis of differences in mRNA expression assayed by QRT-PCR. A $\mathrm{P}$-value of less than 0.05 was considered to be significant.

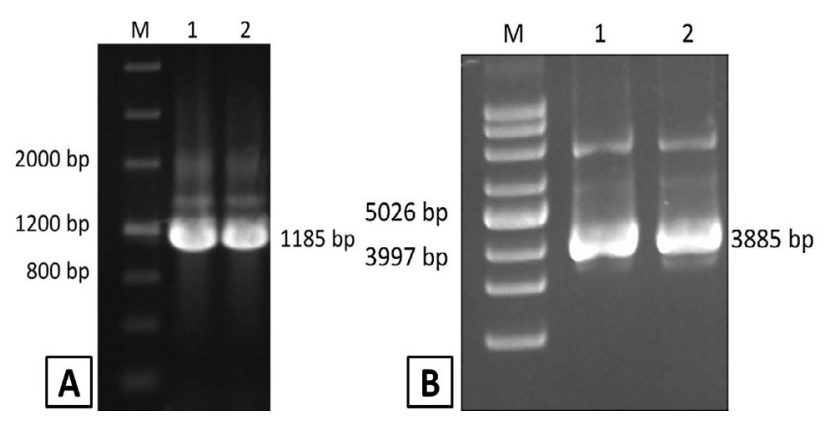

Fig. 1. RT-PCR results for the buffalo $B M P 15$ gene. A: Lane M, marker III; Lane 1-2, RT-PCR product; B: Lane M1, supercoiled DNA ladder; Lane 1-2, pMD-18T-BMP15.

\section{RESULTS}

Cloning and sequence analysis of the water buffalo BMP15 The full-length CDS of BMP15 gene was attained from the buffalo ovary cDNAs by RT-PCR and sequencing. One pair of primers was designed in the conserved regions of the Bos taurus, namely BMP15-F1/BMP15-R1, for amplifying the water buffalo $B M P 15$ gene. Specific PCR products were obtain as seen by agarose/TAE gel electrophoresis (Fig. 1). The size of the products was 1185 $\mathrm{bp}$, consistent with those expected. The sequence results and ORF Finder software analysis showed that the open reading frame (ORF) length size of water buffalo BMP15 gene was 1, 185 bp, and encoded 394 amino acids (Fig. 2).

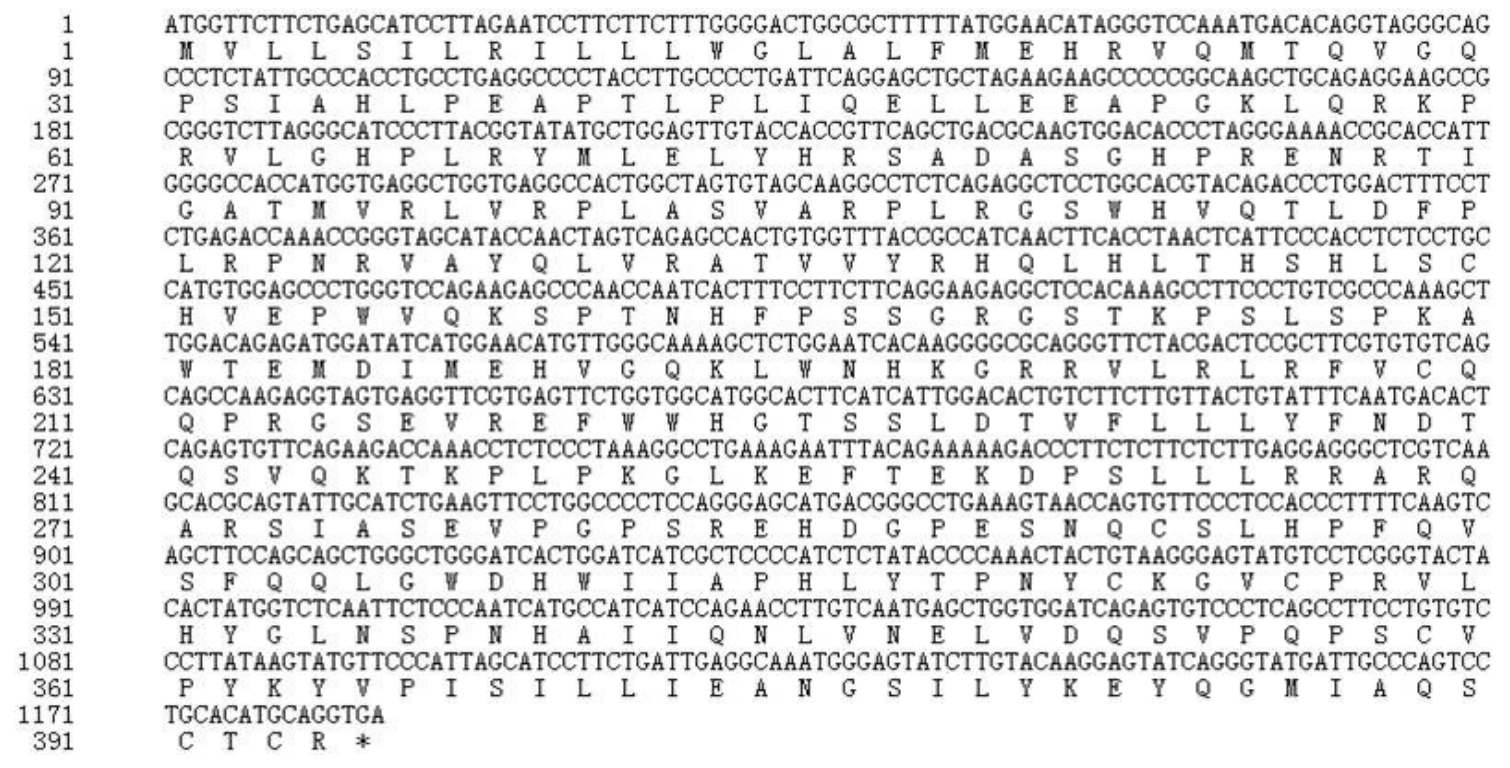

Fig. 2. Buffalo BMP15 nucleotide and amino acid sequences. 


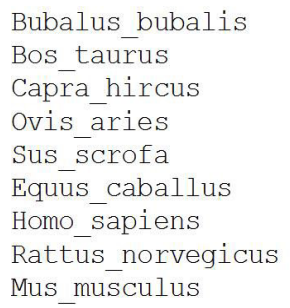

Bubalus bubalis Bos taurus Capra hircus Ovis aries Sus_scrofa Equus caballus Homo sapiens Rattus norvegicus Mus musculus
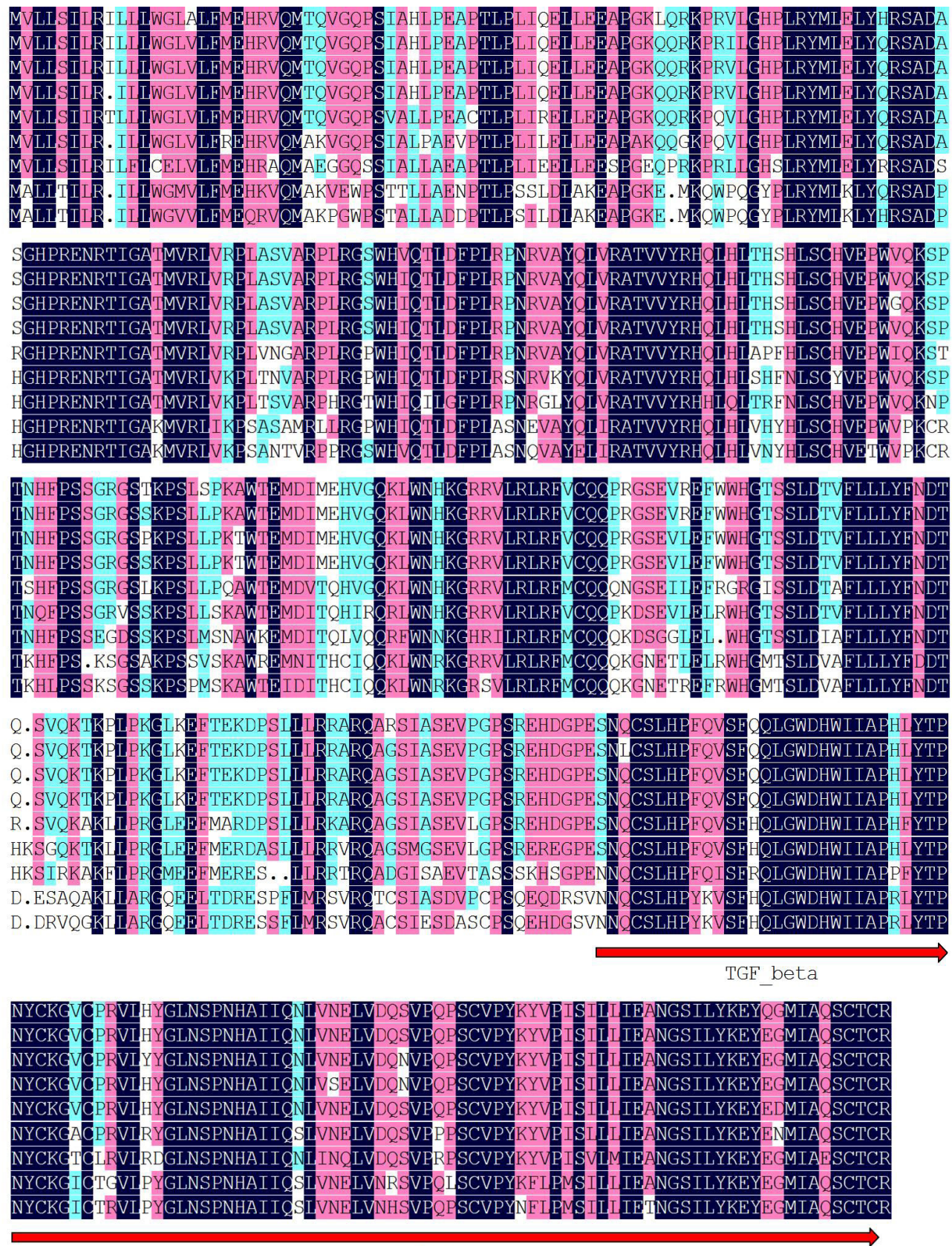

TGF beta

Fig. 3. Multiple alignment and analysis of deduced amino acid sequence of $B M P 15$.

The water buffalo $B M P 15$ protein is the same size as that of Bos taurus, Capra hircus, Equus caballus and Sus scrofa (394 aa), more than that of Ovis aries (393 aa), Homo sapiens (392 aa), Rattus norvegicus (391 aa) and Mus musculus (392 aa), which contained the conserved domains of $B M P 15$ proteins. The InterPro software on the EMBL-EBI Services revealed that protein structures of the water buffalo BMP15 contained the TGFB (278-394)
(Figs. 3, 5). The overall similarity between the water buffalo BMP15 and others' was very high that displayed $79 \%-98 \%$ similarity, showed $98 \%, 98 \%, 90 \%, 79 \%$ and $81 \%$ identity with that of Bos taurus, Ovis aries, Sus scrofa, Mus musculus and Homo sapiens. Figure 4 showed the phylogenetic tree based on amino acid sequence similarity. The water buffalo has the nearest relationship with Bos taurus than with those of other species, belonging to Bovidae. 


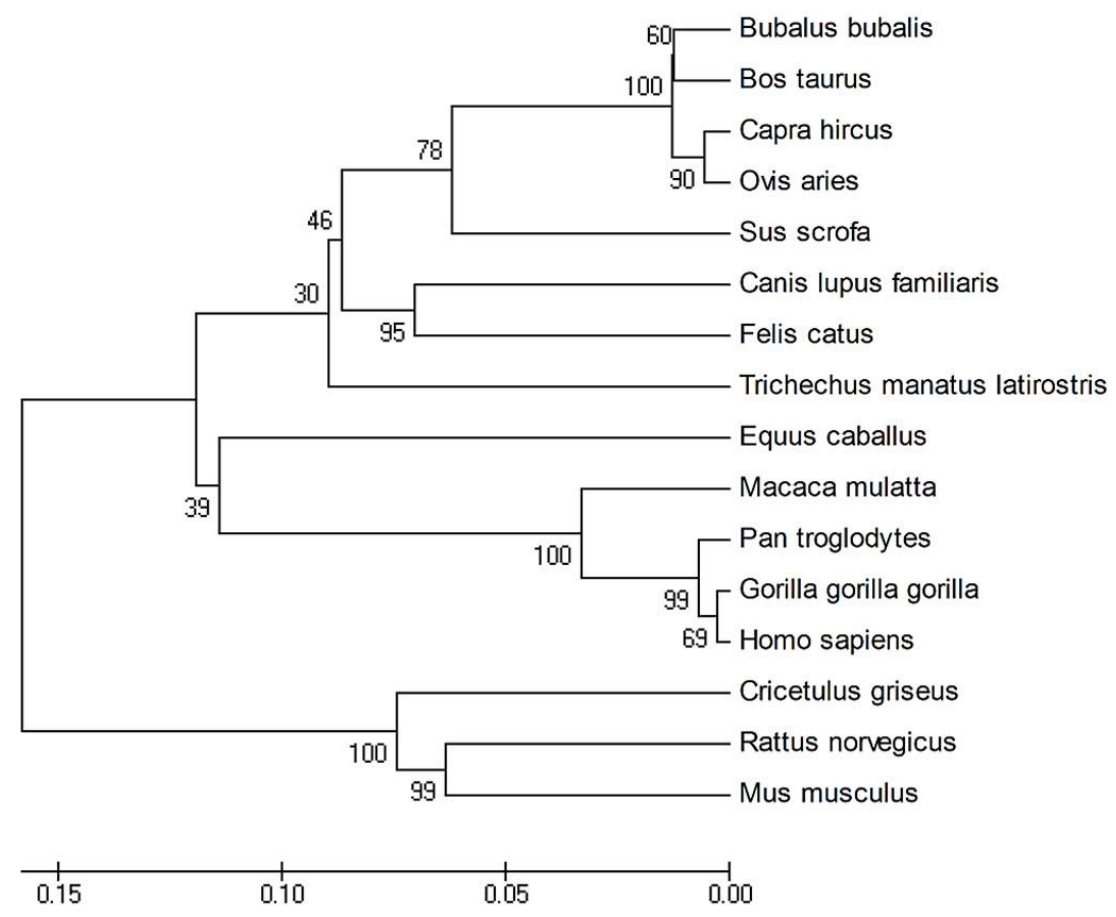

Fig. 4. Neighbor-Joining phylogenetic tree based on the BMP15 protein among some species.

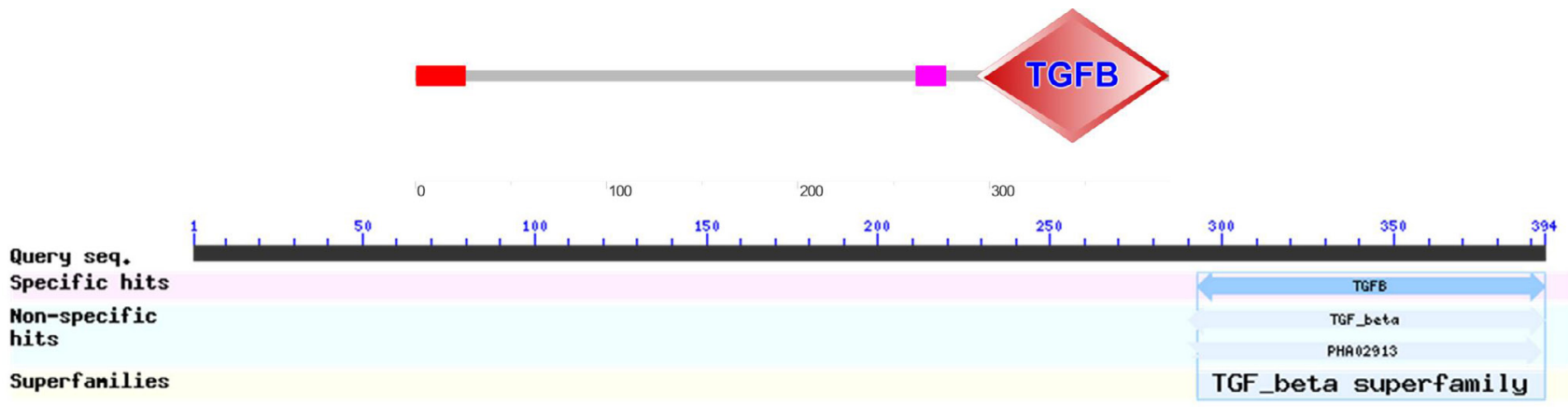

Fig. 5. The protein domain of $B M P 15$.

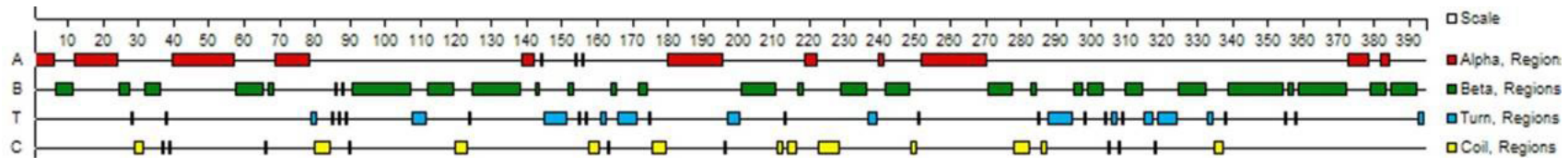

Fig. 6. The secondary structure of buffalo $B M P 15$ protein.

The formula, theoretical $\mathrm{Mw}$ and $\mathrm{pI}$ for the deduced amino acid sequence of $B M P 15$ were $\mathrm{C}_{2027} \mathrm{H}_{3188} \mathrm{~N}_{586} \mathrm{O}_{549} \mathrm{~S}_{16}$, $45.06 \mathrm{kDa}$ and 9.65, respectively. The ProScale software analysis exhibited the water buffalo $B M P 15$ protein was a weakly alkaline protein. Signal peptides predicted showed $B M P 15$ had signal peptide at 25-26 sites by SignIP soft and Smart soft. The Softberry online tool predicted BMP15 was an extracellular protein.

The results of secondary structure prediction indicated that the deduced water buffalo BMP15 contained 14 alpha helices, 29 beta helices, 31 turns, and 21 random coils (Fig. 6). The tertiary structure of buffalo BMP15 protein prediction by I-TASSER server showed that the four species proteins were similar (Fig. 7). 


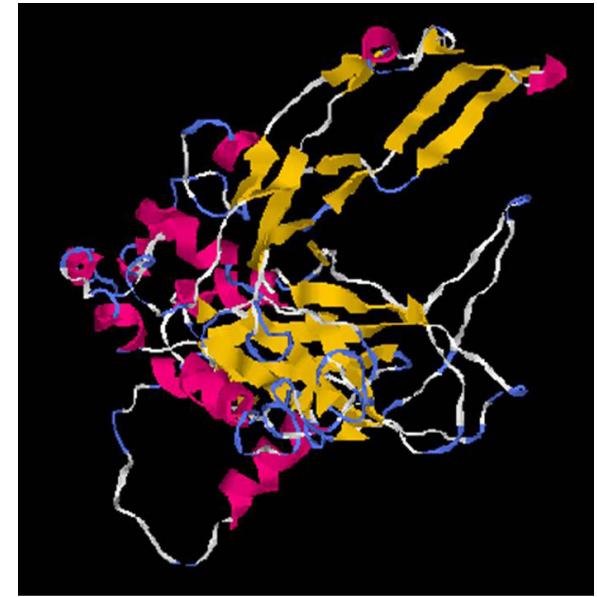

Buffalo

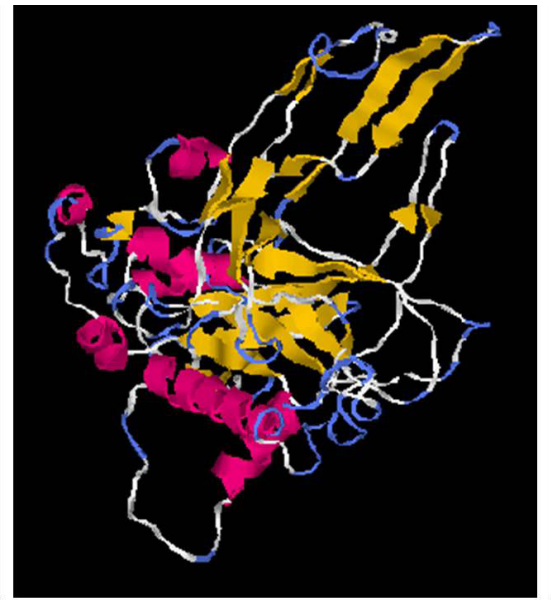

Bos

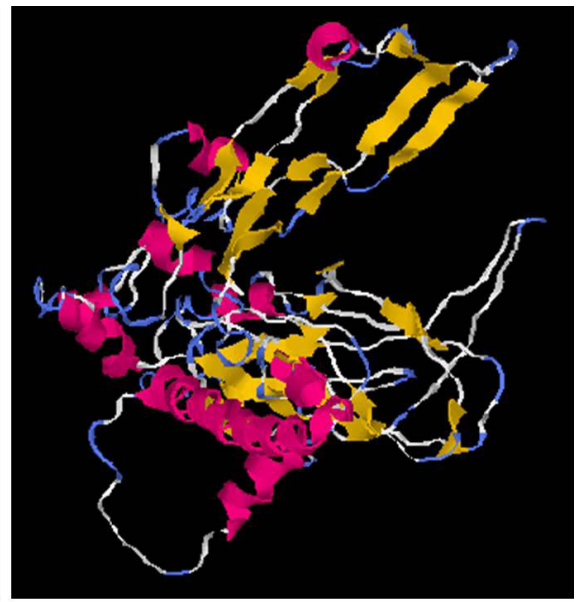

Homo

Fig. 7. The tertiary structure of buffalo, bovine and homo BMP15 protein.

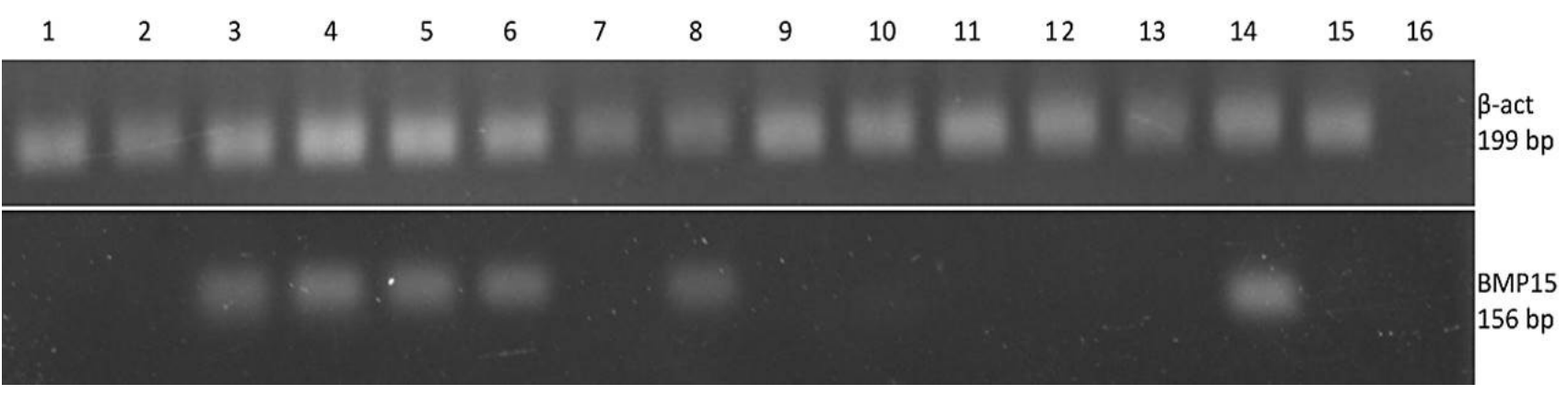

Fig. 8. Agarose gel electrophoresis of PCR product of buffalo ALK6 in different tissues. 1, skin; 2, bone; 3, granular cells; 4 , cumulus cells; 5, ovary; 6 , testis; 7, muscle; 8 , genital ridge; 9 , heart; 10, liver; 11, lung; 12, kidney; 13, brain; 14, hypophysis; 15 , hypothalamus; 16 , water.

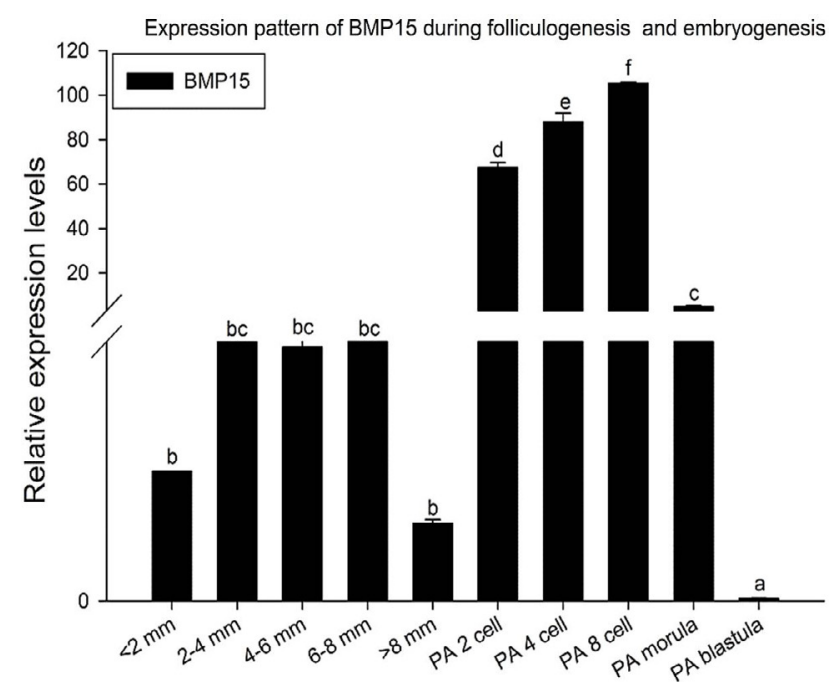

Fig. 9. The expression pattern of BMP15 during buffalo folliculogenesis and embryogenesis.

\section{Tissue distribution of the water buffalo BMP15}

To observe the differential distributions of the BMP15 in water buffalo tissues, 15 buffalo tissues or cells were tested by RT-PCR (Fig. 8). The expression pattern exploration results showed that buffalo BMP15 expressed in the six of 15 tested samples, including ovary, testis, granular cells, cumulus cells, hypophysis and genital ridge. To study the distribution of the water buffalo BMP15 mRNA during folliculogenesis and embryogeneis, COCs of different dimeter follicles and embryos of different development phase were tested by RT-PCR (Fig. 9). The results indicated that $B M P 15$ existed spanning the entire stage of folliculogenesis and embryogenesis. During follicular development, BMP15 firstly up-regulated and then down-regulated, was significantly higher in the COCs of middle dimeter follicles than small and large follicles. Also, it demonstrated the same expression trend in parthenogenetic embryos at different stages of development, continued to rise until morula stage, 

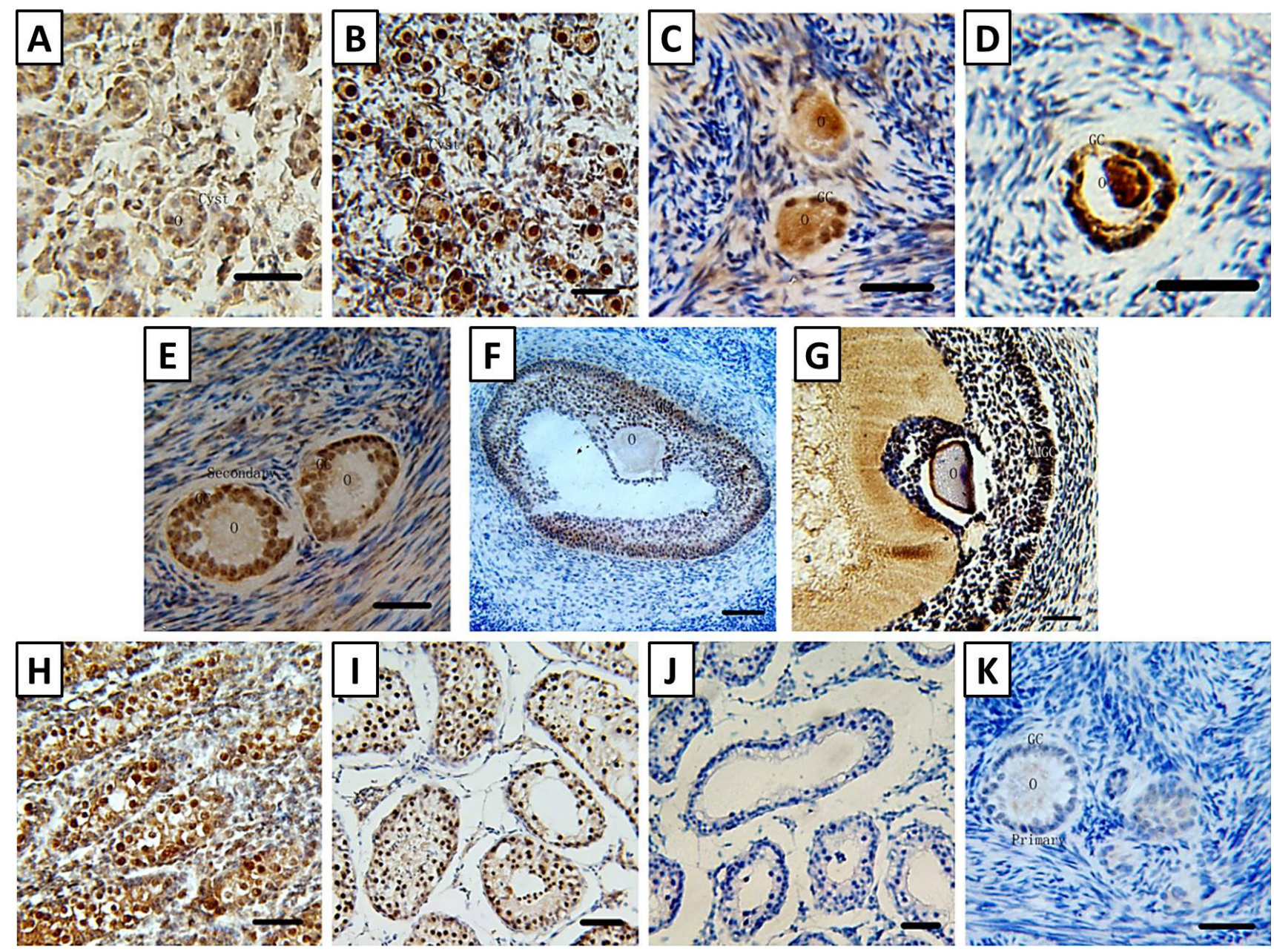

Fig. 10. BMP15 immunoreactivity in the different structures found within buffalo ovaries and testis. A, Primordial follicle in genital ridge of foetus between 60-90 days post concep tion (dpc); B, Primordial follicle in ovary of foetus; C, Primordial follicle in ovary of adult buffalo; D, primary follicle; E, secondary follicle; F, small antral follicle; G, COC of a large antral follicle; $\mathbf{H}$, testis of foetus; $\mathbf{I}$, testis of adult buffalo; $\mathbf{J}$, negative control of testis; $\mathbf{K}$, negative control of ovary. Cyst, primordial cyst; $\mathrm{O}$, oocyte; GC, granulosa cells; CC, cumulus cells; MGC, mural granulosa cells. Scale bars represent $20 \mu \mathrm{m}$.

and fell sharply at blastula stage. The gene expression was very significantly greater in embryogenesis than folliculogenesis, with the exception of blastula stage. Immunohistochemistry showed $B M P 15$ protein was bring into being in all types of follicles (Fig. 10), primordial granulosa cells (Fig. 10C), primary (Fig. 10D), secondary (Fig. 10E), and antral follicles (Fig. 10G) but weak reaction for cumulus cells of antral follicles (Fig. 10G), and absent in theca cells (Fig. 10F, G). BMP15 protein was earliest noticed in primordial cyst of genital ridge of female buffalo foetus (body slanting length was $6-8 \mathrm{~cm}$, amplification of the SRY Gene for sex identification by PCR, data not shown) (Fig. 10A), it exhibited a further conspicuous reaction for BMP15 in follicles than that in granulosa cells and cumulus cells, especially in primordial follicles of ovary of female buffalo foetus (body slanting length was 30-40 cm, data not shown) (Fig. 10B). Also, it exhibited a more conspicuous reaction for $B M P 15$ in primary and secondary follicle than that in small and large antral follicle (Fig. 10B-G). In addition, BMP15 protein was noticed in buffalo foetus testis (body slanting length was 30-40 cm, data not shown) and adult buffalo (Fig. 10H, I).

\section{DISCUSSION}

Water buffalo are an earliest constituent of domestic livestock possessions, and it gives milk and meat, even though which is very little in contrast to cattle, grown up in many countries, such as China, India, Turkey (Yilmaz 
et al., 2012; Kaplan, 2018), Egypt (Wilson, 2012) and so on. The present study focused on molecular cloned buffalo $B M P 15$ gene and estimated the dispersal of BMP15 mRNA and protein in buffalo tissues to conclude whether $B M P 15$ may play a role in the development of follical and embryogenesis in the buffalo.

The name bone morphogenetic protein (BMP) was first given in 1965 by Urist (1965) to the active components in demineralized bone and bone extracts that are capable of inducing bone formation at ectopic sites. In 1988, the first BMPs were isolated, and their cDNAs were cloned by Wozney (1988). In this study, the full-length CDS of $B M P 15$ gene was obtained from the buffalo ovary cDNAs by RT-PCR with direct sequencing, and was found to be 1,185 nucleotides encoding a protein of 394 residues. The homologous comparison showed buffalo BMP15 coding sequence had $98 \%, 98 \%, 90 \%, 79 \%$ and $81 \%$ identity with that of Bos taurus, Ovis aries, Sus scrofa, Mus musculus and Homo sapiens. This is consistent with the results of the zootaxy that further confirmed the reliability of the buffalo $B M P 15$ cDNA sequence. Moreover, the sequence homology levels among species to a certain extent, reflected the phylogenetic relationships, and revealed the stability of the gene encoding protein has significance for the function of organisms in different species structures. The phylogenetic analyses exposed that the nearest relationship existed between the water buffalo and Bos taurus, which revealed that using information of the Bos taurus BMP15 protein to expect the function of the buffalo $B M P 15$ protein by bioinformatic analysis. The SMART online tool and InterPro software on the EMBL-EBI Services for prediction of the buffalo BMP15 protein showed that this protein contained the TGFB domain (278-394). A distinguishing structural feature of the TGF- $\beta$ superfamily is the presence of seven conserved cysteines, which are involved in folding the molecule into a unique three-dimensional structure called a cystine knot by Schlunegger and Grutter (1992). Interestingly, GDF-9 and BMP15 have only six of the seven conserved cysteines; both lack the fourth cysteine that is required for the intersubunit-disulfide bridge (Dube, 1998).

We revealed the expression of mRNA BMP15 gene in buffalo tissues, COCs and embryos as well as in ovary and testis. By using the RT-PCR we were able to demonstrate that ovary, testis, granular cells, cumulus cells, hypophysis and genital ridge expressed mRNA for $B M P 15$. These results are similar to those reported by Silva (2005) for goats, rare minnow Gobiocypris rarus (Zhang, 2014), mouse (Otsuka and Shimasaki, 2002) where BMP15 mRNA were found in ovary, testis, gramular cells, cumulus cells and hypophysis. In this research work, BMP15 existed spanning the entire stage of folliculogenesis and embryogenesis. During follicular development, BMP15 firstly enhanced and then reduced, was considerably greater in the COCs of middle dimeter sized follicles than small and large sized follicles. Also, it indicated the same expression trend in parthenogenetic embryos at different stages of development, sustained to rise until morula stage, and fell sharply at blastula stage. The gene expression was very considerably greater in embryogenesis than folliculogenesis, with the exception of blastula stage. Immunohistochemistry exhibited BMP15 protein was bring into being in all kinds of follicles, primordial granulosa cells, primary, secondary, and antral follicles but weak reaction for cumulus cells of antral follicles, and absent in theca cells. In oocytes exhibited a more conspicuous reaction for BMP15 than in granulosa cells and cumulus cells, especially in primordial follicles. The mRNA expression was considerably higher in the COCs of middle dimeter sized follicles than small and large sized follicles, was reliable with the result of protein expression by immunohistochemistry, which displayed a more prominent reaction for $B M P 15$ in primary and secondary follicle than in small and large antral follicle. These results are similar to those reported for goats (Silva, 2005), brushtail possum (Eckery, 2002), Sus (Li, 2008) where $B M P 15$ mRNA were found as early as in oocytes of primordial follicles, BMP15 mRNA expressed at low levels in immature oocytes and increased to the highest level at $18 \mathrm{~h}$ of IVM, which coincides with the time of cumulus cell expansion. These results explained low expression in large follicle $(>8 \mathrm{~mm})$, but high expression in 2 cell embryo stage in this study, at that time the buffalo genome hadn't been activated. The BMP15 mRNA were found as early as in oocytes of primordial follicles in this study and elsewhere goats et al, is earlier than that found for the mouse, rat, and human (Aaltonen, 1999; Dube, 1998; Elvin et al., 2000; Erickson and Shimasaki, 2003; Jaatinen, 1999; Laitinen, 1998), where they were first observed in oocytes of primary follicles. Surprisingly, the discover of detecting protein of BMP15 in the very early, genital ridge of foetus is intriguing and it suggests that BMP15 maybe play an important fuction in formation, growth and maintenance of primordial follicles in buffalo, as Bodin (2007) showed that homozygous FecX ${ }^{\mathrm{L}}$ adult females displayed an infantile genital tract and the ovaries did not carry any obvious follicular structures in Lacaune sheep.

$B M P 15$ may play diverse roles in regulating early follicular development in different species. Yan (2001) showed that mice lacking BMP15 are subfertile. In contrast, ewes that have naturally occurring inactivating mutations in the BMP15 gene showed follicular development arrested at primary follicle stage and are infertile by 
Galloway (2000). BMP15 is known to stimulate granulosa cell mitosis and early follicular development in rodents as described by Otsuka (2000). Furthermore, the importance of $B M P 15$ for early folliculogenesis is confirmed by the findings of Dong (1996) and Galloway (2000) which showed that $B M P 15$-deficient sheep are infertile because follicle development does not proceed beyond the primary stage. Clearly, the buffalo BMP15 gene cDNAs were successful cloned that provide an important significance for further mining molecular markers associated buffalo reproduciton, exploring its function by TALENs or CRISPR/Cas systems, even breeding new twinning buffalo varieties.

\section{ACKNOWLEDGMENTS}

We acknowledge our friend, colleague and mentor who offer a lot of help in this study. This work was supported by the National Natural Science Foundation of China (No. 31260552) and by Guangxi Natural Science Foundation (Grant No. AA18118041, AB16380042 and 1598013-2).

\section{Statement of conflict of interest}

The authors declare no conflict of interest.

\section{REFERENCES}

Aaltonen, J., 1999. Human growth differentiation factor 9 (GDF-9) and its novel homolog GDF-9B are expressed in oocytes during early folliculogenesis. J. clin. Endocrinol. Metabol., 84: 2744-2750. https://doi.org/10.1210/jc.84.8.2744

Bodin, L., 2007. A novel mutation in the bone morphogenetic protein 15 gene causing defective protein secretion is associated with both increased ovulation rate and sterility in Lacaune sheep. Endocrinology, 148: 393-400. https://doi. org/10.1210/en.2006-0764

Dong, J., 1996. Growth differentiation factor-9 is required during early ovarian folliculogenesis. Nature, 383: 531-535. https://doi.org/10.1038/383531a0

Dube, J.L., 1998. The bone morphogenetic protein 15 gene is X-linked and expressed in oocytes. Mol. Endocrinol., 12: 1809-1817. https://doi. org/10.1210/mend.12.12.0206

Eckery, D.C., 2002. Expression of mRNA encoding growth differentiation factor 9 and bone morphogenetic protein 15 during follicular formation and growth in a marsupial, the brushtail possum (Trichosurus vulpecula). Mol. cell. Endocrinol., 192: 115-126. https://doi.org/10.1016/
S0303-7207(02)00085-0

Elvin, J.A., Yan, C. and Matzuk, M.M., 2000. Oocyteexpressed TGF-beta superfamily members in female fertility. Mol. cell. Endocrinol., 159: 1-5. https://doi.org/10.1016/S0303-7207(99)00185-9

Erickson, G.F. and Shimasaki, S., 2003. The spatiotemporal expression pattern of the bone morphogenetic protein family in rat ovary cell types during the estrous cycle. Reprod. Biol. Endocrinol., 5: 1-9.

Galloway, S.M., 2000. Mutations in an oocyte-derived growth factor gene (BMP15) cause increased ovulation rate and infertility in a dosage-sensitive manner. Nature Genet., 25: 279-283. https://doi. org/10.1038/77033

Huang, B., 2010. Generation and characterization of embryonic stem-like cell lines derived from in vitro fertilization Buffalo (Bubalus bubalis) embryos. Reprod. Domest. Anim., 45: 122-128. https://doi. org/10.1111/j.1439-0531.2008.01268.x

Jaatinen, R., 1999. Localization of growth differentiation factor-9 (GDF-9) mRNA and protein in rat ovaries and cDNA cloning of rat GDF-9 and its novel homolog GDF-9B. Mol. cell. Endocrinol., 156: 189-193. https://doi.org/10.1016/S03037207(99)00100-8

Juengel, J.L., 2002. Growth differentiation factor 9 and bone morphogenetic protein 15 are essential for ovarian follicular development in sheep. Biol. Reprod., 67: 1777-1789. https://doi.org/10.1095/ biolreprod.102.007146

Kaplan, S., 2018. Nucleotide polymorphism of leptin gene in Anatolian Water Buffaloes. Pakistan J. Zool., 50: 1841-1846.

Laitinen, M., 1998. A novel growth differentiation factor-9 (GDF-9) related factor is co-expressed with GDF-9 in mouse oocytes during folliculogenesis. Mechan. Develop., 78: 135-140. https://doi. org/10.1016/S0925-4773(98)00161-0

Letunic, I., Doerks, T. and Bork, P., 2012. SMART 7: Recent updates to the protein domain annotation resource. Nucl. Acids Res., 40: D302-305. https:// doi.org/10.1093/nar/gkr931

Li, H.K., 2008. Differential gene expression of bone morphogenetic protein 15 and growth differentiation factor 9 during in vitro maturation of porcine oocytes and early embryos. Anim. Reprod. Sci., 103: 312-322. https://doi.org/10.1016/j. anireprosci.2006.12.017

Li, X., 2006. Analysis of development-related gene expression in cloned bovine blastocysts with different developmental potential. Cloning 
Stem Cells, 8: 41-50. https://doi.org/10.1089/ clo.2006.8.41

Li, X., Kato, Y. and Tsunoda, Y., 2005. Comparative analysis of development-related gene expression in mouse preimplantation embryos with different developmental potential. Mol. Reprod. Develop., 72: 152-160. https://doi.org/10.1002/mrd.20346

McNatty, K.P., 2003. Oocyte-derived growth factors and ovulation rate in sheep. Reproduction, 61(Suppl.): 339-351.

Otsuka, F., Moore, R.K. and Shimasaki, S., 2001. Biological function and cellular mechanism of bone morphogenetic protein-6 in the ovary. J. biol. Chem., 276: 32889-32895. https://doi.org/10.1074/ jbc.M103212200

Otsuka, F. and Shimasaki, S., 2002. A negative feedback system between oocyte bone morphogenetic protein 15 and granulosa cell kit ligand: Its role in regulating granulosa cell mitosis. Proc. natl. Acad. Sci. U.S.A., 99: 8060-8065. https://doi.org/10.1073/ pnas. 122066899

Otsuka, F. and Shimasaki, S., 2002. A novel function of bone morphogenetic protein-15 in the pituitary: Selective synthesis and secretion of FSH by gonadotropes. Endocrinology, 143: 4938-4941. https://doi.org/10.1210/en.2002-220929

Otsuka, F., 2000. Bone morphogenetic protein-15. Identification of target cells and biological functions. J. biol. Chem., 275: 39523-39528. https://doi.org/10.1074/jbc.M007428200

Petersen, T.N., Brunak, S., von Heijne, G. and Nielsen, H., 2011. SignalP 4.0: Discriminating signal peptides from transmembrane regions. Nat. Meth., 8:785-786. https://doi.org/10.1038/nmeth.1701

Roy, A., Kucukural, A. and Zhang, Y., 2010. I-TASSER: A unified platform for automated protein structure and function prediction. Nat. Protoc., 5: 725-738. https://doi.org/10.1038/nprot.2010.5

Schlunegger, M.P. and Grutter, M.G., 1992. An unusual feature revealed by the crystal structure at 2.2 A resolution of human transforming growth factor-beta 2. Nature, 358: 430-434. https://doi. org/10.1038/358430a0

Shi, D., 2007. Buffalos (Bubalus bubalis) cloned by nuclear transfer of somatic cells. Biol. Reprod., 77: 285-291. https://doi.org/10.1095/ biolreprod.107.060210

Silva, J.R., 2005. Expression of growth differentiation factor 9 (GDF9), bone morphogenetic protein 15 (BMP15), and BMP receptors in the ovaries of goats. Mol. Reprod. Develop., 70: 11-19. https:// doi.org/10.1002/mrd.20127

Singh, S., 2012. Isolation and characterization of oviduct-specific glycoproteins from ampulla and isthmus parts of cyclic and acyclic buffalo for studying differential microenvironment. Appl. Biochem. Biotechnol., 166: 1814-1830. https://doi. org/10.1007/s12010-012-9599-6

Urist, M.R. 1965. Bone: formation by autoinduction. Science, 150: 893-899. https://doi.org/10.1126/ science. 150.3698 .893

Wilson, R.T., 2012. The past and present of and potential for the domestic (water) buffalo in Africa. Trop. Anim. Hlth. Prod., 44: 1367-1373. https://doi. org/10.1007/s11250-012-0097-1

Wozney, J.M., 1988. Novel regulators of bone formation: Molecular clones and activities. Science, 242: 15281534. https://doi.org/10.1126/science.3201241

Yan, C., 2001. Synergistic roles of bone morphogenetic protein 15 and growth differentiation factor 9 in ovarian function. Mol. Endocrinol., 15: 854-866. https://doi.org/10.1210/mend.15.6.0662

Yilmaz, O., Ertugrul, M. and Wilson, R.T., 2012. Domestic livestock resources of Turkey: Water buffalo. Trop. Anim. Hlth. Prod., 44: 707-714. https://doi.org/10.1007/s11250-011-9957-3

Zhang, Y., 2014. Molecular characterization of GDF9 and BMP15 genes in rare minnow Gobiocypris rarus and their expression upon bisphenol A: Exposure in adult females. Gene, 546: 214-221. https://doi.org/10.1016/j.gene.2014.06.013 